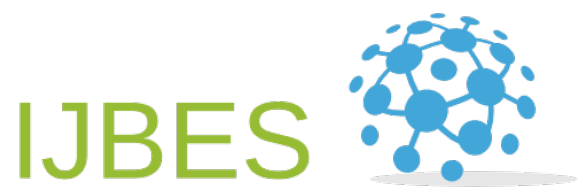

Business Ecosystem \& Strategy
BUSINESS ECOSYSTEM AND STRATEGY

IJBES VOL 1 NO 1 ISSN: 2687-2293

Available online at www.bussecon.com

\title{
A critical approach to human resources practices and training for intellectual capital accumulation \\ Crossref
}

\author{
Selman Duran ${ }^{a *}$, Merve Korkmaz ${ }^{b}$ \\ ${ }^{a}$ Ph.D., School of Business, Istanbul Medipol University, Beykoz, 34500, Istanbul, Turkey. \\ ${ }^{b}$ Institute of Social Science, Istanbul Medipol University, Beykoz, 34500, Istanbul, Turkey
}

\section{ARTICLE INFO}

Article history:

Received 11 April 2019

Received in revised form 25 June 2019

Accepted 12 July 2019

Keywords:
Intellectual Capital
Human Resources Management
Training

Training

\section{JEL Classification:}

M12

M53

\begin{abstract}
A B S T R A C T
With an increasing trend in recent years, it is seen that the concept of intellectual capital is expressed in the global business environment. Intellectual capital covers all invisible assets of the enterprise and is divided into three components: human capital, customer capital and structural capital. With the information age, businesses have accepted the importance of intangible resources rather than material resources and have produced new approaches in this field. In this study, it is aimed to reveal the relationship between human resources practices such as education and motivation and intellectual capital. order to investigate the relationship between intellectual capital, previous studies on intellectual capital and human resources practices were reviewed and evaluated methodologically. This study demonstrated that there is a strong connection between intellectual capital and human resources practices as a finding.
\end{abstract}

(C) 2019 Bussecon International Academy. Hosting by Bussecon International. All rights reserved. Peer review under responsibility of Bussecon International Academy.

\section{Introduction}

Nowadays, with the emergence of the financial gains of intellectual capital to businesses, businesses have started to give the necessary importance to this capital. In the event that the intellectual capital, which is one of the invisible assets of enterprises, is understood and managed correctly, it has gained value in terms of providing competitive advantage, innovative ideas and organizational success to the business.

Intellectual capital covers all invisible assets of the enterprise and is divided into three components: human capital, customer capital and structural capital. Human capital is the most valuable capital to help generating innovative ideas by providing information to the business. Since human capital cannot be purchased by the enterprise and can only be rented, every knowledge and experience produced by human capital needs to be transformed into structural capital. Structural capital is information that employees cannot take home. It creates the infrastructure for the new employee to access this information by ensuring that the information remains in the company even if the employees leave the job. Customer capital is also referred to as relationship capital in

* Corresponding author. Tel.: +90-216-681-51-00; fax: +90-216-531-07555. ORCID ID:0000-0002-2157-5706

E-mail address: sduran@medipol.edu.tr

Peer review under responsibility of Bussecon International Academy.

(C) 2019 Bussecon International. Hosting by Bussecon International. All rights reserved.

http://dx.doi.org/10.36096/ijbes.v1i1.102 
literature. It consists of feedback received from customers by communicating with the external environment of the business. It is very important for keeping the old customers in hand while by bringing new customers to the business.

Every business buys or has the power to buy the material resources. Human resources, on the other hand, is an intangible resource and a powerful resource for making the business superior and successful over other businesses. When human resources are used correctly, it supports the development and growth of human capital by continuously feeding it. In doing so, it utilizes human resources practices and employee training.

The aim of this study is to explain the relationship between intellectual capital and human resources practices and education, of which we have mentioned its importance frequently.

\section{Literature Review}

All Considering the studies on intellectual capital, it has been discussed with issues such as 'the place of intellectual capital in competition, "Measurement, evaluation, reporting, market value of intellectual capital, its place in business performance, its importance in my knowledge community, its interaction with human resources". Although the first definition of intellectual capital was made in 1960, it has not appreciated by businesses for many years. For this reason, every study to be made on intellectual capital as a new concept will provide information, even if a little to the literature. Since intellectual capital gives the competition power required to the enterprises for their subsistence, the importance of the studies to be carried out on this subject are increasing. In addition, considering the studies on human resources, it has taken place with subjects such as 'its place in competition, business performance, importance in information community, organizational citizenship and its place in strategic management in enterprises'. The place of the human resources department in the literature which strives to make the employees who are the real treasure of the enterprises, more efficient, innovative and capable, should be fed continuously.

Table 1: Summary Table of Literature Review

\begin{tabular}{|c|c|c|c|c|}
\hline Author & Subject & Method / approach / model & Components of the Study & Findings \\
\hline Acar 2018 & $\begin{array}{l}\text { Human Resources Management } \\
\text { Policies in Intellectual Capital } \\
\text { Accumulation }\end{array}$ & Survey & $\begin{array}{l}\text { Intellectual Capital, } \\
\text { Human Capital, Human } \\
\text { Resources Management } \\
\text { Understanding }\end{array}$ & $\begin{array}{l}\text { Relationship between policies on } \\
\text { human resources management and } \\
\text { intellectual capital. }\end{array}$ \\
\hline $\begin{array}{l}\text { Gürkan, } \\
\text { Gökbulut \& } \\
\text { Çolak (2015) }\end{array}$ & $\begin{array}{l}\text { The Impact Of The } \\
\text { Intellectual Value Added } \\
\text { Coefficient Components On } \\
\text { Enterprise's } \\
\text { Performance }\end{array}$ & $\begin{array}{l}\text { "Value Added Intellectual } \\
\text { Coefficient" (VAIC) }\end{array}$ & $\begin{array}{l}\text { Intellectual capital, } \\
\text { Intellectual value added } \\
\text { coefficient, Value added, } \\
\text { Positive accounting } \\
\text { theory }\end{array}$ & $\begin{array}{l}\text { Positive effect on business financial } \\
\text { performance by All components of the } \\
\text { intellectual value added coefficient } \\
\text { (human capital, structural capital, } \\
\text { capital employed). }\end{array}$ \\
\hline $\begin{array}{l}\text { Baş, Yangil \& } \\
\text { Aygün } 2014\end{array}$ & $\begin{array}{l}\text { A Content Analysis On The } \\
\text { Dissertations On Intellectual } \\
\text { Capital: 2002-2012 Period }\end{array}$ & $\begin{array}{l}\text { Content Analysis, } \\
\text { Correspondence Analysis }\end{array}$ & $\begin{array}{l}\text { Intellectual Capital, } \\
\text { Content Analysis, }\end{array}$ & $\begin{array}{l}\text { Human capital and relational capital are } \\
\text { relatively less considered, } \\
\text { Transformation of human capital and } \\
\text { relational capital into structural capital } \\
\text { making significant contributions to the } \\
\text { field both in theory and practice, } \\
\text { The majority of postgraduate thesis } \\
\text { studies in the field of intellectual capital } \\
\text { have been conducted in the private } \\
\text { sector. }\end{array}$ \\
\hline $\begin{array}{l}\text { Erdoğan \& } \\
\text { Dönmez } 2014\end{array}$ & $\begin{array}{l}\text { Analysing The Relationship } \\
\text { Between The Intellectual } \\
\text { Capital And Company } \\
\text { Performance: Panel Data } \\
\text { Application }\end{array}$ & Panel Data Regression & $\begin{array}{lr}\text { Intellectual } & \text { Capital, } \\
\text { Human } & \text { Capital, } \\
\text { Structural } & \text { Capital, } \\
\text { Corporate Performance }\end{array}$ & $\begin{array}{l}\text { Positive impact on company efficiency } \\
\text { by human capital and structural capital } \\
\text { as elements of intellectual capital. }\end{array}$ \\
\hline $\begin{array}{l}\text { Kurgun } \\
\text { Akdağ } 2013\end{array}$ & Intellectual Capital & Field Research & $\begin{array}{l}\text { Relationship of } \\
\text { Organization Performance }\end{array}$ & $\begin{array}{l}\text { High level of relationship between } \\
\text { customer capital and organizational } \\
\text { performance, } \\
\text { Lower level relationship between } \\
\text { structural capital and organizational } \\
\text { performance, } \\
\text { A negative relationship has been found } \\
\text { between human capital and } \\
\text { organizational performance. }\end{array}$ \\
\hline
\end{tabular}




\begin{tabular}{|c|c|c|c|c|}
\hline $\begin{array}{l}\text { Erkanlı \& Karsu } \\
2012\end{array}$ & $\begin{array}{l}\text { Intellectual Capital On Value } \\
\text { Chain }\end{array}$ & Review & $\begin{array}{l}\text { Competitive Advantage, } \\
\text { Value Chain , Intellectual } \\
\text { Capital }\end{array}$ & $\begin{array}{l}\text { Relationship between intellectual } \\
\text { capital, value chain, value creation } \\
\text { process and competitive advantage. }\end{array}$ \\
\hline $\begin{array}{l}\text { Molodchik, } \\
\text { Shakina \& } \\
\text { Bykova } 2012\end{array}$ & $\begin{array}{l}\text { Intellectual } \quad \text { Capital } \\
\text { Transformation } \\
\text { Model }\end{array}$ & Regression analysis & $\begin{array}{l}\text { Intellectual capital, } \\
\text { Evaluation, Model, Value } \\
\text { drivers, Transformation } \\
\text { process }\end{array}$ & $\begin{array}{l}\text { positive effect of intellectual capital on } \\
\text { company performance. }\end{array}$ \\
\hline Bozkurt 2011 & $\begin{array}{l}\text { Investigation Of The } \\
\text { Relationship Between Human } \\
\text { Resources Practices, } \\
\text { Organizational Citizenship } \\
\text { Behavior And Financial } \\
\text { Performance: A Research In } \\
\text { The Banking Sector }\end{array}$ & $\begin{array}{l}\text { Pearson correlation analysis, } \\
\text { regression analysis, } \\
\text { hierarchical regression } \\
\text { analysis and factor analysis }\end{array}$ & $\begin{array}{l}\text { Human Resource Practices, } \\
\text { Organizational Citizenship } \\
\text { Behavior, Indicators of } \\
\text { Financial Performance }\end{array}$ & $\begin{array}{l}\text { Relationship between HRM practices of } \\
\text { the legislation banks and organizational } \\
\text { citizenship behaviour, } \\
\text { Mutual interaction between HRM } \\
\text { practices, organizational citizenship } \\
\text { behavior and return on equity (ROE) } \\
\text { which is one of indicators of financial } \\
\text { performance. }\end{array}$ \\
\hline $\begin{array}{ll}\text { Demir } & \& \\
\text { Demirel } 2011 & \end{array}$ & $\begin{array}{l}\text { The Importance of Intellectual } \\
\text { Capital in The Creation of } \\
\text { Competitive Advantage }\end{array}$ & Conceptual & $\begin{array}{l}\text { Competitiveness, } \\
\text { Resource-Based View, } \\
\text { Intellectual Capital }\end{array}$ & $\begin{array}{l}\text { Intellectual capital can use as a } \\
\text { competitive advantage. }\end{array}$ \\
\hline $\begin{array}{l}\text { Karacan } \\
\text { Ergin } 2011\end{array}$ & $\begin{array}{l}\text { Intellectual Capital and } \\
\text { Financial Performance in the } \\
\text { Banking Sector }\end{array}$ & $\begin{array}{l}\text { Calculated Intangible Value } \\
\text { Method }\end{array}$ & $\begin{array}{l}\text { Intellectual capital, } \\
\text { Intangible Assets } \\
\text { Method, Market Value }\end{array}$ & $\begin{array}{l}\text { Highly positively correlation between } \\
\text { intellectual capital and market values. }\end{array}$ \\
\hline $\begin{array}{l}\text { Oğuztürk } \quad \& \\
\text { Alparslan, } 2011\end{array}$ & $\begin{array}{l}\text { Intellectual In E-Commerce } \\
\text { Strategy } \\
\text { Capital Appearance }\end{array}$ & Conceptual & $\begin{array}{l}\text { e-commerce, intellectual } \\
\text { capital }\end{array}$ & $\begin{array}{l}\text { Relationship between intellectual capital } \\
\text { and e-commerce applications. }\end{array}$ \\
\hline $\begin{array}{l}\text { Özdemir } \\
\text { Balkan } 2010\end{array}$ & Elements of Intellectual Capital & $\begin{array}{l}\text { Empirical Research } \\
\text { (Correlation Research) }\end{array}$ & $\begin{array}{l}\text { Contributions } \\
\text { Enterprises }\end{array}$ & $\begin{array}{l}\text { Positive relation between human capital } \\
\text { and structural capital elements and } \\
\text { business performance. } \\
\text { Positive relation between customer } \\
\text { capital elements and customer } \\
\text { satisfaction }\end{array}$ \\
\hline $\begin{array}{l}\text { Özevren } \\
\text { Yıldız } 2010\end{array}$ & $\begin{array}{l}\text { A Research on Identifing of } \\
\text { The Measurement Methods } \\
\text { And Criterions of Intellectual } \\
\text { Capital }\end{array}$ & Review & $\begin{array}{l}\text { Measurement Methods and } \\
\text { Criteria, Measurement and } \\
\text { Reporting methods }\end{array}$ & $\begin{array}{l}\text { Sector-specific criteria should be } \\
\text { determined for the intellectual capital } \\
\text { activity report and determined to be } \\
\text { measured objectively. }\end{array}$ \\
\hline Yıldız 2010 & $\begin{array}{l}\text { The Effect of Intellectual } \\
\text { Capital on Business } \\
\text { Performance: A Research in } \\
\text { Banking Sector }\end{array}$ & Survey & $\begin{array}{l}\text { Impact on Enterprise } \\
\text { Performance }\end{array}$ & $\begin{array}{l}\text { Positive effects on both subjective and } \\
\text { objective performance by intellectual } \\
\text { capital including human, organizational } \\
\text { and customer capital, } \\
\text { Elements of intellectual capital effect } \\
\text { subjective performance more than } \\
\text { objective performance, } \\
\text { Customer and organizational capital } \\
\text { effect subjective performance more } \\
\text { positively. }\end{array}$ \\
\hline Görmüş 2009 & Intellectual Capital & Review & $\begin{array}{l}\text { Increasing Importance of } \\
\text { Human } \quad \text { Resources } \\
\text { Management }\end{array}$ & $\begin{array}{l}\text { Relationship between sustainable } \\
\text { competitiveness and intellectual capital }\end{array}$ \\
\hline $\begin{array}{l}\text { Karacaer } \\
\text { Aygun } 2009\end{array}$ & $\begin{array}{l}\text { The Effect of Intellectual } \\
\text { Capital on Firm Performance }\end{array}$ & $\begin{array}{l}\text { Correlation and Linear } \\
\text { Multiple } \\
\text { Analysis }\end{array}$ & $\begin{array}{l}\text { Intellectual capital, firm } \\
\text { performance, value added } \\
\text { intellectual capital } \\
\text { coefficient, } \\
\text { capital }\end{array}$ & $\begin{array}{l}\text { Positive relation between structural } \\
\text { capital efficiency associations, } \\
\text { intellectual capital coefficents and firm } \\
\text { performance. }\end{array}$ \\
\hline $\begin{array}{l}\text { Toraman, } \\
\text { Abdioğlu } \quad \& \\
\text { İşgüden } 2009\end{array}$ & $\begin{array}{l}\text { Evaluation Of Intellectual } \\
\text { Capital And Management } \\
\text { Accounting In The Innovation } \\
\text { Process Businesses }\end{array}$ & Conceptual Framework & $\begin{array}{l}\text { Innovation, Intellectual } \\
\text { Capital, } \\
\text { Accounting, } \\
\text { Competition. }\end{array}$ & $\begin{array}{l}\text { Relationship between intellectual } \\
\text { capital and innovation process, } \\
\text { managerial accountig }\end{array}$ \\
\hline
\end{tabular}




\begin{tabular}{|c|c|c|c|c|}
\hline Aydemir 2008 & $\begin{array}{l}\text { Intellectual Capital: Theory } \\
\text { Development and New } \\
\text { Perspectives }\end{array}$ & Review & $\begin{array}{l}\text { New Approach; Human } \\
\text { Resources; }\end{array}$ & $\begin{array}{l}\text { Relationship between intellectual } \\
\text { capital, social capital and women } \\
\text { entrepreneurs' ability }\end{array}$ \\
\hline Ekinci 2008 & $\begin{array}{l}\text { Transition to Human Resources } \\
\text { Practice }\end{array}$ & Review & Employee Productivity & $\begin{array}{l}\text { Relation between intellectual capital and } \\
\text { employees productivity in public } \\
\text { institutions }\end{array}$ \\
\hline $\begin{array}{l}\text { Öztürk } \\
\text { Demirgüneş } \\
2008\end{array}$ & $\begin{array}{l}\text { Intellectual Capital from the } \\
\text { Perspective of Corporate } \\
\text { Governance }\end{array}$ & Conceptual & $\begin{array}{l}\text { Corporate Governance, } \\
\text { Intellectual Capital }\end{array}$ & $\begin{array}{l}\text { Relationship between intellectual } \\
\text { capital and corporate governance }\end{array}$ \\
\hline
\end{tabular}

\begin{tabular}{ll}
\hline Yörük \& Erdem & Intellectual Capital and its Empirical \\
$\mathbf{2 0 0 8}$ & Elements
\end{tabular}

Impact on the Financial Considerable effort to using Performance of intellectual capital assets,

Automotive Sector Basic elements of the firms

Companies Listed on performance are attached to their Istanbul Stock Exchange

physical assets,

Relationship between intellectual capital and business performance.

\begin{tabular}{|c|c|c|c|c|}
\hline $\begin{array}{l}\text { Alagöz \& } \\
\text { Özpenirci } 2007\end{array}$ & $\begin{array}{l}\text { Intellectual Assets and } \\
\text { Reporting }\end{array}$ & Review & Information Society & $\begin{array}{l}\text { There is a lack in the accounting system } \\
\text { about intangible assets }\end{array}$ \\
\hline $\begin{array}{l}\text { Atak \& Atik } \\
2007\end{array}$ & $\begin{array}{l}\text { Importance of Continuous } \\
\text { Training in Organizations and } \\
\text { Effect on the Process of } \\
\text { Creating a } \\
\text { Organization }\end{array}$ & Review & $\begin{array}{l}\text { Knowledge Management, } \\
\text { Continuous Training, } \\
\text { Training and Development, } \\
\text { Learning Organization. }\end{array}$ & $\begin{array}{l}\text { The continuous training system created } \\
\text { in the organization will lead the } \\
\text { employees to do their jobs better and to } \\
\text { be innovative at the same time. }\end{array}$ \\
\hline Bek 2007 & Human Resources Management & Survey & Training and Development & $\begin{array}{l}\text { Training implemented in the enterprises } \\
\text { is not sufficient and the training gap and } \\
\text { development program to both employees } \\
\text { and managers. }\end{array}$ \\
\hline $\begin{array}{l}\text { Kayali, Yereli \& } \\
\text { Ada } 2007\end{array}$ & $\begin{array}{l}\text { A Study The effect of } \\
\text { Intellectual Capital on Firm } \\
\text { Valuation with the Help of the } \\
\text { Value Added Intellectual } \\
\text { Coefficient of Ante Pulic }\end{array}$ & $\begin{array}{l}\text { Correlation And Multiple } \\
\text { Regression Analysis }\end{array}$ & $\begin{array}{l}\text { Intellectual Capital, Firm } \\
\text { Value, Value Added } \\
\text { Intellectual Coefficient }\end{array}$ & $\begin{array}{l}\text { Strongly positive relationship between } \\
\text { human capital and technology firms } \\
\text { efficiency, } \\
\text { No relation between human capital and } \\
\text { profitability, productivity and market } \\
\text { value of firms. }\end{array}$ \\
\hline $\begin{array}{l}\text { Marangoz \& } \\
\text { Biber 2007 }\end{array}$ & Human Resources Practices & Survey & $\begin{array}{l}\text { Business Market } \\
\text { Performance, competitive } \\
\text { advantage, job enrichment } \\
\text { factors }\end{array}$ & $\begin{array}{l}\text { Relation between market performance in } \\
\text { general performance in terms of } \\
\text { providing competitive advantage and } \\
\text { personnel selection and job enrichment } \\
\text { factors. }\end{array}$ \\
\hline Muradova 2007 & Human Resources Management & Review & $\begin{array}{l}\text { Importance of Training and } \\
\text { Development }\end{array}$ & $\begin{array}{l}\text { Cost of training should not be considered } \\
\text { as a cost element but as an investment. }\end{array}$ \\
\hline $\begin{array}{l}\text { Ölçer \& Sanal, } \\
\text { 2007; }\end{array}$ & $\begin{array}{l}\text { Intellectual Capital } \\
\text { Management in Businesses }\end{array}$ & & $\begin{array}{l}\text { Intellectual capital, } \\
\text { intellectual assets, } \\
\text { intangible } \quad \text { assets, } \\
\text { knowledge management }\end{array}$ & $\begin{array}{l}\text { Relationship between intellectual capital } \\
\text { and corporate governance }\end{array}$ \\
\hline $\begin{array}{l}\text { Işevi \& Çelme } \\
2005\end{array}$ & $\begin{array}{l}\text { The New Treasure: Becoming } \\
\text { More Competitive with } \\
\text { Intellectual Capital }\end{array}$ & Review & $\begin{array}{l}\text { Competitive Power, } \\
\text { Intellectual Capital }\end{array}$ & $\begin{array}{l}\text { Institutions, communities and societies } \\
\text { that have the knowledge can use } \\
\text { knowledge as a social, political and } \\
\text { economic power. }\end{array}$ \\
\hline $\begin{array}{l}\text { Yereli \& Gerşil } \\
2005\end{array}$ & $\begin{array}{l}\text { Methods Used } \text { To Measure } \\
\text { And Report Intellectual } \\
\text { Capital }\end{array}$ & Conceptual & $\begin{array}{lr}\text { Intellectual } & \text { capital, } \\
\text { Measuring, } & \text { Reporting, } \\
\text { Turkish } & \text { accounting } \\
\text { system } & \end{array}$ & $\begin{array}{l}\text { Difficulty of valuation of intellectual } \\
\text { capital }\end{array}$ \\
\hline
\end{tabular}




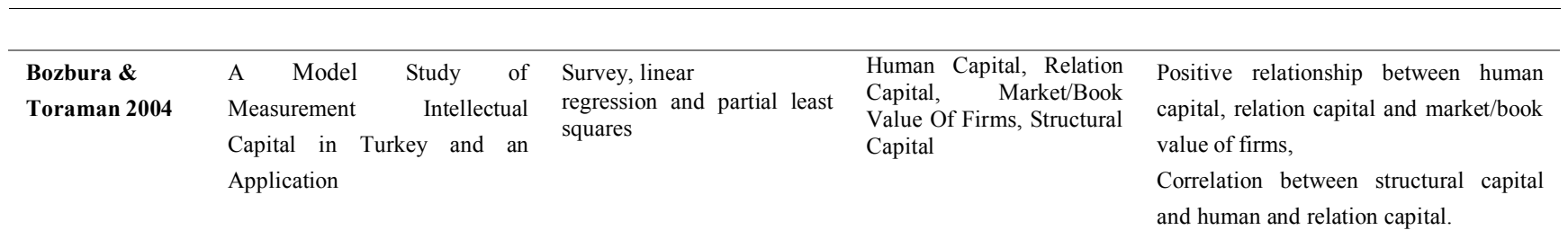

\begin{tabular}{|c|c|c|c|c|}
\hline Emrem 2004 & $\begin{array}{l}\text { Conceptual Analysis of } \\
\text { Intellectual Capital and Its } \\
\text { Components }\end{array}$ & Conceptual Framework & $\begin{array}{l}\text { Intellectual Capital, } \\
\text { Components of Intellectual } \\
\text { Capital }\end{array}$ & $\begin{array}{l}\text { Relationship between intellectual } \\
\text { capital and strategic decision making }\end{array}$ \\
\hline $\begin{array}{l}\text { Erdil, Alpkan \& } \\
\text { Biber } 2004\end{array}$ & $\begin{array}{l}\text { An Investigation On The } \\
\text { Relationship Between Human } \\
\text { Resources Applications and } \\
\text { Organizational Performance }\end{array}$ & $\begin{array}{l}\text { Pearson correlation analysis, } \\
\text { correlation analysis }\end{array}$ & $\begin{array}{l}\text { Organizational } \\
\text { Performance, } \\
\text { Human Resources } \\
\text { Applications }\end{array}$ & $\begin{array}{l}\text { Positive effect on employees' innovation } \\
\text { tendency by job enrichment, job } \\
\text { expansion and personnel selection } \\
\text { process from HRM practices. }\end{array}$ \\
\hline Kanıbir 2004 & $\begin{array}{l}\text { Intellectual Capital as a New } \\
\text { Source of Competitive Power } \\
\text { and Organizational } \\
\text { Reflections on Performance }\end{array}$ & Conceptual & $\begin{array}{l}\text { Intellectual } \\
\text { Organizational } \\
\text { performance, } \\
\text { Competitiveness }\end{array}$ & $\begin{array}{l}\text { Positive relations between brain power of } \\
\text { members and management skills }\end{array}$ \\
\hline Karacan 2004 & $\begin{array}{l}\text { Intellectual Capital and } \\
\text { Management }\end{array}$ & Review & $\begin{array}{l}\text { Management, Customer } \\
\text { Capital, Business Value, }\end{array}$ & $\begin{array}{l}\text { Relationship between intellectual capital } \\
\text { and business success. }\end{array}$ \\
\hline $\begin{array}{l}\text { Özer, Özmen \& } \\
\text { Saatçioğlu } 2004\end{array}$ & $\begin{array}{l}\text { Differentiating Characteristics } \\
\text { of Knowledge Workers and } \\
\text { Human Resources management }\end{array}$ & Conceptual Framework & $\begin{array}{lr}\text { Knowledge } & \text { workers, } \\
\text { knowledge management, } \\
\text { human } & \text { resources } \\
\text { management. } & \end{array}$ & $\begin{array}{l}\text { Relationship between the characteristics } \\
\text { of individual and organizational learning } \\
\text { such as knowledge level, learning level, } \\
\text { level of questioning assumptions, ability } \\
\text { to work as a team. }\end{array}$ \\
\hline Şerbetçi 2003 & Human Resources Capital & Review & $\begin{array}{l}\text { Importance of Human } \\
\text { Capital in Terms of } \\
\text { Enterprise Management }\end{array}$ & $\begin{array}{l}\text { Intellectual capital studies in Turkey } \\
\text { focus on structural capital and } \\
\text { accounting and finance science branches. }\end{array}$ \\
\hline
\end{tabular}

Source: Authors' own study

In the article by İşevi and Çelme titled "New Treasure in the Information Age in 2005: Catching the Competition with Intellectual Capital", it has been concluded that "in enterprises, in society and society which have the knowledge, knowledge can be used as a social, political and economic power, those who do not have the knowledge will be able to survive in a world where they are powerless by embracing the firm's own culture and employees". In the article by Yereli and Gerşil titled "Measuring and Reporting Methods of Intellectual Capital in 2005", it has been concluded that "Intellectual capital is among the priority issues in information-oriented enterprises. Intellectual capital plays an important role in achieving the long-term goals of enterprises. Therefore, the interest shown in the financial and physical management of enterprises should be shown in intellectual capital. More value should be given to human capital at the stage in which work processes are redefined. Because it is a person who changes processes, re-identifies, stores information and uses it when necessary. Therefore, businesses have achieved to significantly improve performance of the employees". In the article by Yörük and Erdem titled "The Impact of Intellectual Capital and Its Components on the Financial Performance of Automotive Companies Listed in Istanbul Stock Exchange (ISE) in 2008", it has been concluded that "Considering the financial statements of 12 automotive companies whose shares are listed on the ISE, automotive companies operating in Turkey make an effort to give importance to intellectual capital assets, although still the main factors affecting the business performance are physical assets". In the article by Y1ldiz titled "The Impact of Intellectual Capital on Business Performance in 2010: A Research in the Banking Sector" it has been concluded that "As a result of examining the managers according to demographic characteristics; As age, managerial experience, working time and position increase, the perception of the elements of intellectual capital and the importance attached to it increases. Researches on intellectual capital have shown that customer capital is the highest and structural capital is the least reported element of intellectual capital". In addition, in the article it has been determined that more importance should be given to different intellectual capital elements in different sectors. Major studies in the field have been summarized with their major findings in the Appendix A.

In the article by Erdil, Alpkan and Biber titled "An Investigation on the Research of Relationship Between Human Resources Practices and Organizational Performance in 2004", it has been concluded that "As a result of the research findings, it has been found that the process of job enrichment, job expansion and personnel selection from human resources management practices positively affects the innovation tendency of the employees. The recruitment process has been one of the most influential factors in human resources management practices. Significant increase in the performance of human resources management practices has become important in the business world. The effects of human resource management practices were observed during the formation of mergers and partnerships, growth or contraction strategies, and changes in the life cycle of the organization. Successful changes can be achieved through effective human resources management". In the article by Bayat titled "Strategic Quality of Human Resources Management in 2008", it has been concluded that "Human resources management contributes to the achievement of the goals and objectives of the enterprise, helps the enterprise to maintain its competitive advantage and increases the quality of their working lives with various applications such as managing the right recruitment process, giving employees an opportunity to develop their knowledge, skills and abilities through various training programs, ensuring their commitment to work and 
business, motivation. In this sense, human resources management is not only a support for the fulfillment of other functions of the enterprise, it is also a strategically important form of management that should take part in the formation and implementation of strategies". In the article by Görmüş titled "Increasing Importance of Intellectual Capital and Human Resources Management in 2009", it has been concluded that "It has been found that the most important element of intellectual capital is human capital. The successful execution of this capital can only be ensured through the effective maintenance of human resources. In this respect, for sustainable competitiveness, enterprises should expand their human resources management. Managers have a characteristic that directly affects senior management and has a voice in the decisions to be taken in terms of human resources models, business management's mission, vision, strategy, policy and values. Achieving and sustaining competitive advantage will increase with the contribution of human resources". In the article by Acar titled "Human Resources Management Policies in Intellectual Capital Accumulation in 2018: Süleyman Demirel University's example”, it has been concluded that "The outcomes of the human resources management policy and the level of human capital and the structural and customer capitals formed together with make the human resources management policies to be followed important".

\section{The importance of the accumulation of intellectual capital in competitive environment}

Nowadays, businesses are trying to survive under increasing competition conditions. In this process of information age, human has increased its value day by day. By replacing the material resources in the centre of the enterprise with information, many concepts have emerged which can provide competitive advantage and one of these concepts, intellectual capital, has added value to its value. In addition, considering that people will dominate the financial resources of the enterprise, it should be understood that the value of employees with knowledge must be above all other. Forethought and generating new ideas has gained importance in this age in which technology is advancing rapidly, the demands of the customers differentiate day by day, the ideas included in the future are constantly renewed and even the expectations between yesterday and tomorrow are not the same. Generating new ideas is not a value that a machine can do. Therefore, knowledge and people are needed to generate new ideas. Businesses should find ways to access information and make it a goal of the business to use it to generate new ideas where necessary. Businesses that achieve this condition will make themselves different from other businesses, will become a forward-looking enterprise and will make themselves superior in the competition. At the same time, the enterprise will increase productivity through the products or services of which outputs it will take by using the intellectual capital while producing a product or service and, by providing less output and more output, will reduce business costs and increase profits. Intellectual capital, according to Itami (1987), has been defined as an invisible important asset which is gaining importance increasingly in the globalizing world and which provides competitive advantage. (Özevren, Yıldiz 2010; Rudez, Mihalic)

According to Stewart (1997), intellectual capital is packaged useful information. Stewart emphasized that intellectual capital is the sum of everything that is known and adopted by all employees of the enterprise or that will provide competitive advantage (Y1ldiz, 2010; Stewart, 1997). Knowing and managing the correct definition of intellectual capital is important for the businesses. In the early 2000s, the importance of intellectual capital has begun to be understood globally. Studies have been made to measure, report and manage intellectual capital in many parts of the world, and these studies still continue. (Özevren, Star 2010). The term of intellectual capital is defined by the Organization for Economic Development and Cooperation (OECD) as "the economic value of the intangible assets owned by enterprises, more clearly of the organizational capital and human capital” (Karacan 2004; Nerdrum 2001). Intellectual capital has become more important in today's world by giving up the idea that a company is just a tangible and perceptible asset with the definitions of intellectual capital. It is concluded that intangible resources should be considered as important as the tangible assets within the company.

\subsection{Elements of intellectual capital}

The enterprises which will increase the value of their products or services produced in the information age and provide superiority in competition, will be meaningful together with the elements of intellectual capital (İșevi, Çelme 2005). When the effect of market value of an enterprise on tangible and intangible assets is examined, it is thought that approximately $80 \%$ of enterprises are composed of invisible assets. In case the effect of market value of an enterprise on tangible and intangible assets is examined, it is thought that approximately $80 \%$ of the enterprises are composed of invisible assets (Y1ld1z 2010 ; Dewhurst and Navarro, 2004). Although intellectual capital is not a material resource, it affects the difference between book value and market value of the enterprise (Ölçer \& Sanal 2007). It will be possible to divide market value into financial capital and intellectual capital. Intellectual capital is examined in three dimensions as Human Capital, Structural Capital and Customer Capital (Table-1). These dimensions constantly feed intellectual capital. The ability to generate new ideas, which is the building blocks of intellectual capital, is achieved through the effective and efficient use of human capital. Employee knowledge and training underlying human capital has continuously gained value and continues to gain in this context. Since human capital is not an enterprise-dependent capital, human capital expires when employees leave their jobs. Businesses, on the other hand, should support the structural capital and ensure that information remains in the company even if the employee leaves the company. Customer capital, which is the last dimension of intellectual capital, is important for the maintenance of enterprises. Because the main reason of existence of businesses is to make profit by selling the services or products produced by them. Customer capital enables the business to keep existing customers and gain new customers by connecting it with the external environment and carrying current customer requests to the business. 
Table 1: The place of intellectual capital in the value chart of the enterprise

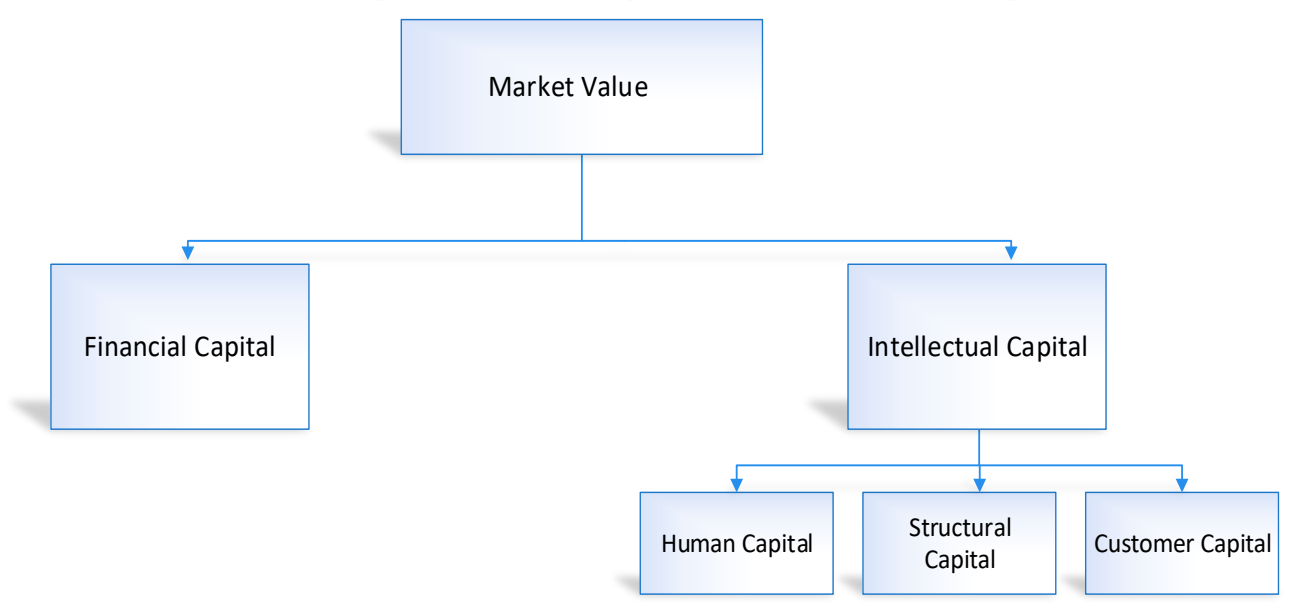

Source: İşevi \& Çelme; Thomas Stewart, "Intellectual Capital: New Wealth of Organizations”, 1997

\subsection{Human Capital and Its Importance for Businesses}

Each business desires to protect and maintain its existence. In order to achieve this, it should provide preference superiority by separating itself from other enterprises. One of the most valuable assets of a business is undoubtedly human capital. Human capital are the elements such as knowledge, skills, talent and experience, etc. that belong to each of the employees, and which makes it different from the others. Although human capital forms the cornerstones of the enterprise, it is not an element belong to the enterprise. Businesses can only rent human capital, which is the most valuable asset of organizations, in certain periods (Kanıbir, 2004). Human capital includes employees' knowledge, their problem-solving abilities and capacities, life philosophies, creativity, entrepreneurship and leadership skills, the functions they present in organizational processes and the qualities of these functions (Oğuztürk, Alparslan 2011). If the knowledgeable, skilled and experienced employees in their field do not use these skills to add value to the business, they are not considered as human capital. Businesses should always question why their skilled employees do not produce innovative activities, and should give continuously material and moral support to their employees in order to produce innovative activities. In this regard managers have great responsibility. The majority of employees can be transformed into human capital, if the company thinks of its own employees as a source of innovation and a source of power, rather than a machine. When human capital is not seen as a continuous, never ending resource, and the opportunities and values that should be given to the employees are not given, the employees will change their businesses at the first opportunity since they will not be happy in the enterprise.

Edvinsson likens Intellectual capital to a tree and states that human capital is the sap that provides the development of the tree (Karacan 2004; Steward). Businesses generally think of human capital only as muscle strength. However, employees have more value than muscle strength and this value should be reflected in the financial statements (Uzay, Savaş 2003; Roslender, 2000). The talents and experiences of the enterprises depend on the employees. The larger these two factors, the higher the price of products and services and enterprise can be strong against their competitors (İșevi, Çelme 2005). People working in an enterprise create and use human capital as they dedicate their time and talent for innovation (Emrem 2004; Stewart, 1997). Not all employees are considered as human capital, the employees who can be considered as human capital should add value to the enterprise by generating innovative ideas. If this value is not added, human will be no different than artificial intelligence. No matter what business we do today, if we don't generate innovative ideas for this business, we won't be able to offer striking advantages to customers, and the profit for the enterprise will not last long term (İnce 2005; Kırım, 1999). Human capital is formed by the employees and since it does not belong to the enterprise, capital loss occurs when the employees leave their jobs. Making capital a source of the enterprise rather than the employee is very important in terms of reaching the source even if the employee leaves the enterprise. In order to make more use of human capital, it is necessary to support the transformation of the implicit knowledge connected to the employee into open information and to transfer this open information to structural capital. Companies that achieve this, keep the information gained by the employee within the enterprise if the employee leaves the job (Emrem 2004). Not all information may be revealed or it may not be possible to keep it within the enterprise. If so, the best way is to increase employee's loyalty and prevent the employee from leaving the job.

Human capital is constantly increasing its importance because it is a power that cannot be imitated by others. In human capital, the real need is to add value and knowledge to the business rather than the raw work. Thomas Stewart emphasized the importance of ideas and creativity: "Money talks, but it can't think; machines often do better than human can, but they cannot invent". In fact, the fact that differentiates human capital from other sources is the ability of people to produce innovation, to create difference of choice and to renew the potential of enterprises. For this reason, human capital is thought as the most important element of intellectual capital. In other words, the more you strengthen the human capital, the stronger the intellectual capital. The education, upbringing and strengthening of human capital will positively affect intellectual capital (Y1ldiz 2010; Williams, 2004, p.368). One of the important 
contributions of human capital is directly increasing the financial results of the enterprise. It is observed that Investments in human capital have a positive relationship with the share value of the company (Emrem 2004; Pfau, 2001) and increase the market share by $43 \%$. As a result of the research conducted in 750 enterprises in the USA and European countries, it was found that human capital is the most important determinant of the market value (Gürbüz 2018 p.25). The market value of Microsoft is $\$ 450$ billion, while the value of physical assets is only $\$ 10$ billion. The reason for its high market value is the conversion of human capital into income (Görmüş 2009; Seçkin 1999).

We can support the importance of human capital with these words of Kurşunmaden: "People hold their human capital in their own hands and give their capital to institutions in order to provide a benefit in return. This benefit may be related to the field of finance as well as non-financial fields. It is possible for businesses to have access to human capital that is appropriate for them. The important thing is to keep this human capital in hand and the obligation to make use of it as high as possible" (Demir \& Demirel 2011; Kurşunmaden 2009).

\subsection{Structural Capital and Its Importance for Enterprises}

Structural capital ensures that the information that is important for the enterprises remains with the enterprise regardless of the person, even if loss of employee is experienced. Basically, there are two aims of structural capital which may be mentioned. The first is to regulate the transfer of information and to take measures to prevent loss of information. The second is that employees have timely access to data, experts and information (Yereli \& Gerşil 2005; Stewart 1997). Even if the employee is equipped with as much knowledge, skills and talent, he will not be able to use them for the benefit of the enterprise when structural capital is insufficient. According to Bontis, an enterprise cannot maximize its intellectual capital if the systems and procedures used by it to achieve its objectives are insufficient (Görmüş 2009). Structural capital and human capital feed each other. As we have mentioned in human capital, employees can leave the company together if it is not converted into structural capital. In addition, since structural capital is the only intellectual capital element that depends on the enterprise, it is an element that enterprises should value. In our country, the focus on the science branch of structural capital and accounting and finance in the post-graduate thesis studies on the subject of intellectual capital between 2002-2012 shows the importance of this element (Baş, et al. 2014). Structural capital has also aimed at storage of information and access to information. Since employees cannot have access to information at the enterprises where the structural capital is insufficient, the innovations that it wants to produce will fail or it will not be able to produce innovations due to this deficiency.

\subsection{Customer Capital and Its Importance for the Enterprise}

The company needs the customer, directly or indirectly, to survive. Customer is of vital importance for the enterprise and with the knowledge coming from the customer, the enterprise will always carry itself to the upper level. Enterprises should constantly follow what is happening around them in order to survive. Customer capital includes connections with the external environment such as customer loyalty, firm reputation, relationships with distributors and wholesalers etc. and covers the entire environment out of the enterprise that can create added value for the enterprise (Özdemir \& Balkan 2010; Ertuğrul, 2000). In short, customer capital is the analysis of the enterprise's environment. Enterprises are established to meet the demands and needs of their customers. Every enterprise should strengthen the customer capital required to do this and obtain new information and strengthen the quality of the services or products to be produced depending on the customer. In cases where communication is broken, loss of customer would be an inevitable end. This end would raise costs bringing the responsibility of searching new customers for the enterprise. That's is because gaining new customers is more difficult and costlier than keeping old customers in our hands and would cause financial and moral damages for the enterprise. We should not forget that the related customer capital is the basis for survival of the enterprise and we should consider it all the time.

\section{Table 2: Intellectual capital components}

\begin{tabular}{|l|l|l|}
\hline Human Capital & Structural Capital & Customer Capital \\
\hline Knowledge and competencies & Technology & Relations with customers \\
\hline Experience & Information system & Enterprise image \\
\hline Education & Databases & Brands \\
\hline Creativity and innovation & Business Processes & Distribution channels \\
\hline Other features such as leadership, entrepreneurship & Culture and values & Business processes \\
\hline Competence in design & Management philosophy & Skills related to hand labor \\
\hline Competencies in model development & Patents, Copyrights, Trade secrets & Database \\
\hline Competence in production stage & Relations with customers & Software programs \\
\hline Commitment & Relations with suppliers & \\
\hline Quality in working area relations & Relations with corporate brands & \\
\hline
\end{tabular}

Sources: Erkanlı \& Karsu 2012; Giuliani \& Marasca, 2011. 


\section{The importance of the accumulation of intellectual capital in competitive environment}

One of the units in which the intellectual capital and the enterprise are affiliated is undoubtedly human resources. There are many types of practices of the human resources such as defining the jobs of all employees in the enterprise, recruitment and training of human resources. With these practices, human resources add value to the value of intellectual capital.

With the job analysis, intellectual capital enables definition of duties including the duty of the person to be recruited to carry out the works as expected from him/her hired person and ensures the hired person to act in accordance with these expectations. Knowing the job description, the employee focuses only on those subjects and gains expertise on these subjects. With this expertise in intellectual capital, employees form the human capital of the enterprise. With the recruitment process and intellectual capital, the placement of persons to be hired in the right positions according to their knowledge, skills and experiences and in line with the definition of the job is valuable for the enterprise. When this placement is incorrect, the employee will not be successful in his / her job and both the quality of the resulting work will decrease and the employee will not be able to carry out his / her work and therefore he/she will leave the job and the process will return to the beginning resulting in adverse factors like loss of time, loss of business.

In respect of employee training and intellectual capital; employee training is studied in two groups: induction and employee training. It aims to ensure the employee to adapt to the corporate culture during the induction process and helps the employee to overcome this process more easily and enables the employee to discover his / her knowledge and skills in a shorter period of time. Employee training can, however, be given after the employee starts to work according to job of the employee or they may be trainings to increase the motivation of employees. When the employee is assigned for the job, it is difficult to ensure him/her to be $100 \%$ eligible for the job. Even if this compliance is ensured, employees will lose their knowledge in time and their adaptation to work will decrease. In order to increase the suitability for the job, employees should be trained on the issues that they lack. If the training is not provided, employees will cause loss to the enterprise as they will produce with defects in their work in connection with increased cost of work, loss of time, loss of customer due to customer dissatisfaction and similar problems. Some managers do not see the damages caused by the lack of training and consider the training given to the employee as a cost and find it meaningless and unnecessary. The continuous education system created in the organization will affect the human resources of the intellectual capital as it will lead the employees to do their jobs better and to be innovative at the same time. Human resources and practices and training in detail are as follows.

\section{Effective role of human resources}

One Enterprises have the power to purchase each any tangible asset. As a result, the intangible assets of the enterprises have gained importance rather than the tangible assets presently. The human being, which appears to be the basic building block of enterprises, is the most valuable one of the intangible resources. It increases the importance of human resources in order to keep its qualified employees connected to the enterprise and benefit from their knowledge and experience. Human resources cover everyone from the top manager to the subordinate in a firm. In fact, it also includes the employees from whom the enterprise may potentially benefit outside the enterprise (Şimşek, et al. 2016:3). In general terms, human resource management is defined as "all functions and activities that enable the effective management of the organization by complying with the laws in a way that human resources are beneficial to the organization, individual and the environment in any organizational and environmental environment Ac (Acar 2018). Human resources management is a process of organizational management of the human resources or business in order to achieve the purpose determined by the enterprise (Erdil, et al. 2004). The management of human resources is based on the creation of an active workforce and its efficient use. Human resource management puts people at the center of the enterprise and performs its human-centered functions (İnce, 2005). Enterprises such as Motorola, Nokia, Microsoft and IBM, who have realized the importance of intellectual capital, have become competitive for new brains (Görmüş 2009).

The development and increase of the intellectual capital of an enterprise depends to a large extent on the individuals working in the enterprise. If the employee leaves the company, his knowledge, skills and abilities are also lost. Human resources are always needed to keep these resources in our hands.

\subsection{Job Analysis}

Job analysis is the process of collecting information about the job and systematically evaluating and analyzing this information in order to ensure that a job can be performed in the most efficient way (Şimşek et al. 2016: 12). The information may be left out again due to the loss of employees due to the wrong selection of the persons hired for the positions that are not fully analyzed in terms of job. The required characteristics of the person to be employed will also be obtained as a result of the job analysis. With the analysis of the job, the doors of the information are also opened together with the employee to be hired. With the analysis of the job, employees know what is expected of them to do in their job and accordingly, they continue their jobs in a more competent way.

\subsection{Recruitment}

It is the placement of the most suitable candidate by considering the necessary knowledge, experience and skills of the human need that has occurred in the enterprise. It is important to look at our internal resources as a priority for the vacant position. That's because, in this way, the performance and productivity of the employees are increased by giving the opportunity to promote the employees within the enterprise and to make department changes upon the requests of our employees who are not satisfied with their current position. If there is no suitable candidate in our internal resources, it would be right to hire new 
employees for the enterprise. The recruitment of a new employee for the enterprise will provide new blood to the enterprise. For example, employees working in the enterprise may become blunt in their job after a period. He/she may struggle with problems even with simple solutions or may not be willing to solve them because he is used to the problems. The new employee will be willing to solve these problems as he/she faces them for the first time. During the recruitment process, while the enterprise is looking for qualified employees, the job seekers will apply to the appropriate enterprises for them. In order to be successful in finding qualified job seekers, it is important to attract job seekers to the enterprise. Due to their adoption of an organizational culture based on a supported and entertaining working environment, which job seekers apply extensively, Google carries out the recruitment process effectively. Google supports the creativity and development processes by providing employees with free working hours to turn them into human capital. For example; Google engineers use $20 \%$ of their time to develop project in new and interesting products (Gürbüz 2018). The fact that the employees produce projects without being dependent on anyone in the enterprise also increases their job satisfaction and increases their loyalty to the enterprise. Google has made it a part of the enterprise by providing its employees with opportunities that are not available at most enterprises. The resignation rate; the personnel turnover rate is only 3\% in Google enterprise (Willock 2007). The reason Google enterprise is preferred so much is because its employees are satisfied with their enterprise. This enterprise, striving to transform the vast majority of its human resources into human capital, is one of the "most valuable 100 brands" in the world. Google company now has reached a brand value of $\$ 142.8$ billion (Branding Türkiye, 2019). The selection of employees who will care, believe and continuously support the intellectual capital management will facilitate the strengthening and sustaining this capital as the enterprise will start the process of selecting employees.

\subsection{Performance Evaluation}

Performance is all the benefits that employees or working groups provide to the business. Since the success and failure of the employees will also affect the business, the high performance of the employees will provide profit for the business. Ensuring that employees use their talents after recruitment is the criterion that encourages them. Performance evaluation enables employees to act in accordance with the goals and objectives of the business. It can also be defined as a tool that evaluates all of the employees' knowledge, skills and attitudes to their contribution to the success of the business. It determines whether the employees in the enterprise fulfill their duties, powers and responsibilities. The purpose of performance evaluation is to ensure that employees' success is aligned with the objectives of the business by ensuring the improvement of weaknesses by evaluating the success of the employee. In order to make the performance evaluation more effective, it is divided into three groups as administrative, developmental and research purposes. (Gürbüz 2018)

Administrative purposes: It is used in administrative decisions such as remuneration, upgrade, transfer and dismissal.

Developmental purposes: It is offered for career planning, preparation of training and development programs, counseling and guidance support and feedback of strengths and weaknesses.

Research purposes: It is used to establish the performance bond between the employee and the business by examining performance-related conditions such as job satisfaction, setting future goals in determining motivation levels.

Performance evaluation supports human capital by ensuring that employees' weaknesses are improved and that employees gain innovation, quality and hard-to-find product/service production capabilities. It also helps us achieve organizational justice by retaining qualified employees in the hands of the business, as it will also help us identify which employee can be dismissed from the business in case of quitting. Every business wants to make the most of its scarce resources. Performance evaluation aims to increase the efficiency of human capital in businesses by providing high employee productivity to the enterprise by making maximum use of human resources. Performance evaluation will keep employees vigorous and motivate them to work. Highly motivated employees will continuously contribute to human capital.

\subsection{Employee Training}

Education has continuously gained and continues to gain value throughout human life. Knowledge, which is one of the main features that distinguishes man from machines, is an issue that needs to be seriously considered by enterprises as it is obtained through education. The simple definition of education is to have knowledge and skills on a specific topic. Education also means, "to increase the skill of a certain field of work and to ensure it is performance is better" (Muradova 2007; Tortop 1994). Businesses also need training to survive. They care and need education in order to be the business who is able to access information and have new knowledge and production by evaluating the knowledge (Atak \& Atik 2007). Training in businesses is a necessary need to increase the efficiency of human resources. Businesses are divided into two categories as orientation and employee training.

\subsection{Orientation}

It is the trainings that are given in order to shorten the duration of the adaptation of the persons who have started to work to the workplaces and to understand the work more quickly. Its main purpose is to enable the new employee and the organization to speak the same language. These trainings will also help employees to reduce uncertainty and anxiety that may arise when employees enter an unknown environment (Gürbüz 2018: 178). Regardless of how much information is provided to the new employees in the recruitment process, it is normal for the employee to experience shock and concern about new tasks (Gürbüz 2018: 178; Louis 1980). The new employee should be informed about the historical background of the workplace, the products produced, the organizational structure, the rules that are important in the organization and the policies of the organization (Buluç, 1998). The duration of the information may be extended up to six months in large enterprises and may be completed within three months in smaller enterprises such as banks (Şimşek, et al. 2016). 
These trainings may vary depending on the principles, objectives and targets that the enterprise attaches importance to. Business training can be exampled as communication techniques, stress management, time management and teamwork. It may be right to repeat the trainings over time as employees who are accustomed to work may forget the trainings given.

\subsection{Employee Training and Employee Training Process}

It aims to select the most suitable candidate by questioning the suitability of the employees in the recruitment process and their level of training. However, no matter which techniques are used, it is very difficult to choose the right employee for the job. Because it is often not possible to identify people correctly and identify their characteristics (Muradova 2007). It would be reasonable to provide training to make the selected employee suitable to work. In addition, with the ever-changing, developing and growing technology and new applications, employees need training even if they fully adapt when they are employed. Some employees do not need training by saying that they know everything. The training needs will be met by the institution or individually and will ensure the professionalization of the person at work again. While training for the employee may seem only a cost for some businesses, it will actually make a big profit for the business as it will reduce the disruptions in the business and will make a profit for the business well above the cost spent. Employees will increase their loyalty to the business by feeling more valuable with the training provided. Accordingly, loss of human capital in the business will be prevented.

Developing the intellectual capital pool is not a process that is completed by hiring the right employees. They should continue to be trained to provide innovation and creativity in knowledge production. Adding information to the information on which employees are employed should be among the core tasks of a business. Businesses that can do this will increase their value and gains by increasing the importance of intellectual capital. The training process consists of four stages as illustrated in figure 1:

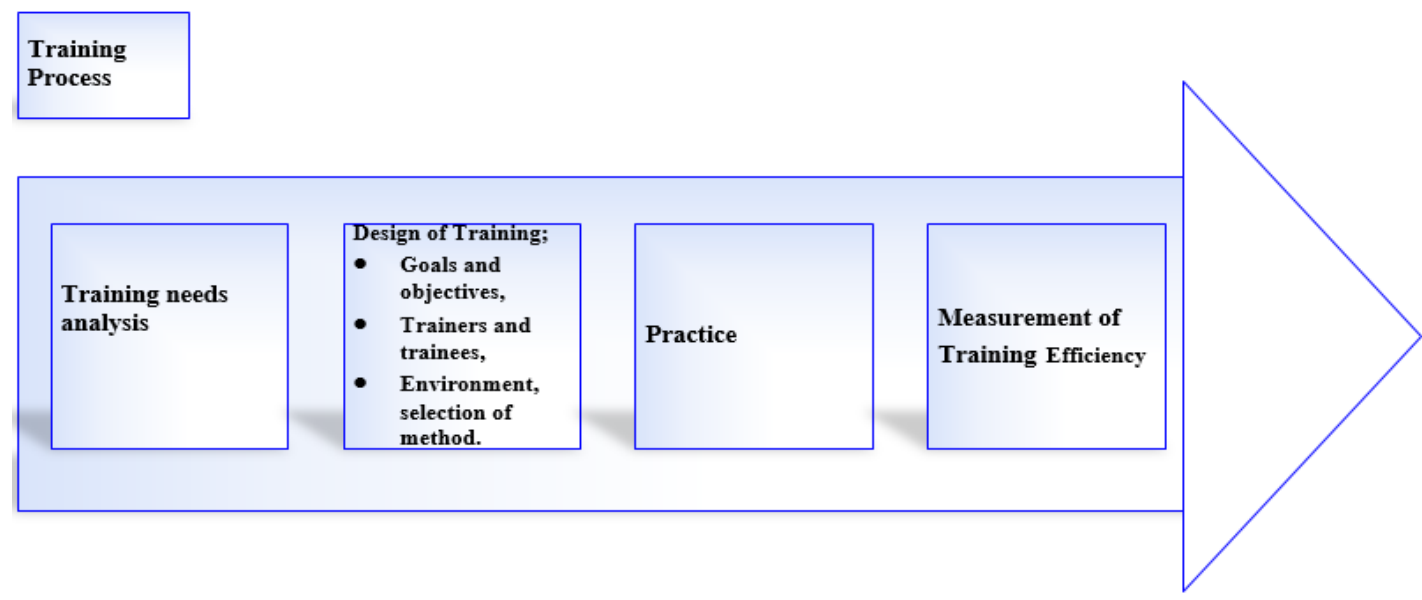

Figure 1: raining Process Stages

Source: Gurbuz, 2018:179

The training to be given in the business is expected to provide a value at the end of it. Considering that each training is a cost for the business, it is important to provide the maximum level of efficiency to be obtained from the training by correctly determining the subject of the training and who will give it to which employees. Training activities in the business should be planned in a way that will impose continuous training understanding to employees and ensure the continuity of the training (Atak \& Atik 2007). It will not be right to attribute any problems that may occur in the business to the lack of training. First of all, it will be more appropriate to go to the root of the problem and find out the real reason and plan the training in the business if the root of the problem is training. Training may not only be problem-based. It is important to provide support to the development of employees in trainings such as problem solving, body language and diction which are seen as a constant need within the business. Researches have shown that businesses do not give sufficient importance to education. For instance, in a study conducted, only $27 \%$ of the organizations identified training needs analysis for their employees (Gürbüz: 2018, 181; Saari \& johndon \& Mclaughlin \& Zimmerler: 1988). As the second stage, the design of the training provides the goals and objectives of the training to be determined and achieved. If the trainers and employees know these goals and objectives, they will conclude what they will focus on. Trainers who do not have sufficient knowledge or who cannot fully transfer what they know, experience problems in transferring information to the group to be trained. The trainer can be a member of departments such as human resources training department and patient services education department in the business, but may also come from outside. What is important in selecting trainers is that they are experts in their fields. The group to be trained should be determined for the group of employees in need of training. The training will not only provide a lot of information to the employees but also will increase the morale and motivation of the employees. For example, trainings such as paper marbling education, terrarium preparation, yoga, calligraphy and etc. are 
provided by businesses depending on the personal tastes of the employees. Directing each employee to the trainings they are interested in will prevent both time and money loss.

The methods of training should be determined by the experts who will train. Training methods vary depending on the subject of the training. Some training and development methods are as follows;

Table 3: Training and development methods

\begin{tabular}{l}
\hline On the job training \\
\hline Orientation \\
\hline Conference \\
\hline Internship \\
\hline Business Games \\
\hline Cultural education \\
\hline Computer support training \\
\hline
\end{tabular}

Source: Gurbuz, 2018:184

\subsubsection{Measurement of Training Activity,}

It is important for the efficiency of the process that it provides a benefit to the business after the training. When businesses provide a training, they want to reach to the conclusion that how much of this information is conveyed to their employees and that it is successful, therefore they receive feedback after the training. There are four levels of receiving this feedback.

First Level: Feedback is gathered through questionnaires and open-ended questions at the end of the training. Often it is insufficient to reflect the truth. Employees may wish to hide their negative feedback, or may fall for the pleasant conversation rather than the information provided by the instructor, as they are inadequate.

Second Level: After the training, the test questions are solved or by measuring the information before the first training and the same test is given after the training and a meaningful benefit is sought by comparing the difference.

Third Level: It looks at the increase in performance in jobs by aiming to find out whether the purpose of the training has been achieved after training.

Fourth Level: It is the most effective level of education measurement. After the training, it is examined whether the added values in the business increase.

\section{Conclusion}

In the globalizing world, businesses have turned to different sources in order to maintain their existence and competitive advantage. As a result of this orientation, it is seen that only financial resources of businesses are insufficient and importance should be given to intangible resources for competitive advantage. Intellectual capital is formed by the combination of human capital, structural capital and customer capital which will provide competitive advantage for businesses. Human capital is the total contribution of employees who possess knowledge, skills, experience and innovative ideas to the business. The conversion of the information provided by the employees to the information belonging to the business is called structural capital. Customer capital provides the connection between the external environment and the business.

Human resources practices and training nurture the concept of intellectual capital by providing benefits to the business in terms of recruitment of trainable and knowledgeable employees in the recruitment process, and in the training and evaluation of them. In conclusion, there is a positive relationship between intellectual capital and human resources practices and education.

\section{Acknowledgements}

This study has been sponsored by Bussecon International Academy. 


\section{REFERENCES}

Acar, O. K. (2018). Entelektüel Sermaye Birikiminde İnsan Kaynaklari Yönetimi Politikalari: Süleyman Demirel Üniversitesi Örneği. Avrasya Uluslararasl Araştırmalar Dergisi, 6(14), 193-215. DOI: 10.33692/avrasyad.510626

Aksoy, B. (2005). Bilgi Teknolojisinin Yarattığı Örgütsel Değiş̧im: Nasıl Bir İnsan Kaynakları Yönetimi?. Bilgi Dünyası, 6(1), 58-77.

Alagöz, A., \& Özpeynirci, R. (2007). Bilgi Toplumunda Entelektüel Varliklar Ve Raporlanmasi. Afyon Kocatepe Üniversitesi İktisadi ve İdari Bilimler Fakültesi Dergisi, 9(2), 167-184. http://dergipark.org.tr/akuiibfd/issue/1630/20444

Atak, M., \& Atik, İ. (2007). Örgütlerde sürekli eğitimin önemi ve öğrenen örgüt oluşturma sürecine etkisi. Journal of Aeronautics and Space Technologies, 3(1), 6370.

Aydemir, O. (2008). Entelektüel Sermaye: Yeni Yaklaşimlar. Bölüm Yazarlari Prof. Dr. Rlza AŞIKOĞLU, 99.

Baş, M., Misirdali Yangil, F., \& Aygün, S. (2014). Entelektüel sermaye alanında yapılan lisansüstü tez çalışmalarına yönelik bir içerik analizi: $2002-2012$ dönemi. Uluslararası Yönetim İktisat ve İsletme Dergisi, 10(23), 207-226. http://dx.doi.org/10.17130/ijmeb.2014.10.23.618

Bek., H. , (2007). İnsan Kaynaklari Yönetiminde Eğitim Ve Geliştirme Etkinliği (Örnek Bir Uygulama). Selçuk Üniversitesi Sosyal Bilimler Enstitüsü Dergisi, 1(17), 107-120.

Bozbura, F. T., \& Toraman, A. (2010). Türkiye'de entelektüel sermayenin ölçülmesi ile ilgili model çalışması ve bir uygulama. ITÜDERGISII/d, 3(1).

Bozkurt, S. (2011). İnsan Kaynaklari Uygulamalari, Örgütsel Vatandaşlik Davranişi Ve Finansal Performans Arasindaki İlişkinin İncelenmesi: Bankacilik Sektöründe Bir Araştirma. Istanbul Management Journal, 22(70), 36-62. http://dergipark.org.tr/iuiieyd/issue/9200/115520

Demir, Y., \& Demirel, E. T. (2011). Rekabet Avantajı Yaratmada Entelektüel Sermayenin Önemi. ISGUC The Journal of Industrial Relations and Human Resources, 13(1), 81-104. http://dergipark.org.tr/isguc/issue/25474/268710

Ekinci, F. (2008). Kamu personel yönetiminden insan kaynakları uygulamasına geçişin çalışanların verimliliğine etkisi. Maliye Dergisi, 155, 175-185.

Emrem, E. , (2004). Entelektüel Sermaye Ve Bileşenlerinin Kavramsal Analizi . İş, gü̧̧ Endüstri İlişkileri ve İnsan Kaynakları Dergisi, cilt 6, sayı 1, no 186

Erdil, O., Alpkan, L. H., \& Performans, L. B. K. U. Ö. (2004). İnsan Kaynaklari Uygulamalariyla Örgütsel Performans Arasindaki İlişkileri Araştirmaya Yönelik Bir İnceleme. Dokuz Eylül Üniversitesi İktisadi Ve İdari Bilimler Fakültesi Dergisi, 19(2).

Erdoğan, M., \& Dönmez, A. (2014). Entelektüel Sermaye İle İşletme Performansi Arasindaki İlişkinin İncelenmesi: Panel Veri Uygulamasi Analysing The Relationship Between The Intellectual Capital And Company Performance: Panel Data Application. Journal Of International Social Research, 7(29).

Erkanli, H., \& Karsu, S. (2012). Değer Zincirinde Entellektüel Sermaye. Ömer Halisdemir Üniversitesi İktisadi ve İdari Bilimler Fakültesi Dergisi, 5(2), 216.

Gürkan, S., Gökbulut, R. İ., \& Çolak, N., (2015). Entelektüel Katma Değer Katsayisi Bileşenlerinin İ̧̧letmelerin Finansal Performansi Üzerindeki Etkisi. Ekonomik ve Sosyal Araştırmalar Dergisi, Cilt 11, Yll 11, Sayl 2, 45-64.

Görmüş, A. Ş. (2009). Entelektüel Sermaye Ve İnsan Kaynaklari Yönetiminin Artan Önemi. Afyon Kocatepe Üniversitesi İktisadi ve İdari Bilimler Fakültesi Dergisi, 11(1), 57-75. http://dergipark.org.tr/akuiibfd/issue/1627/20382

Gürbüz, S. (2018) -İnsan Kaynakları Yönetimi 2. Baskı

Hafizullah, B. E. K. (2007). İnsan Kaynaklari Yönetiminde Eğitim Ve Geliştirme Etkinliği (Örnek Bir Uygulama). Selçuk Üniversitesi Sosyal Bilimler Enstitüsü Dergisi, l(17), 107-120 http://dergipark.org.tr/akuiibfd/issue/1627/20382

İşevi, A. S., \& Çelme, B. (2005). Bilgi çağında yeni hazine: Entelektüel sermayeyle rekabeti yakalamak. Bilgi Dünyast, 6(2), 251-267.

Kanıbir, H. (2004). Yeni Bir Rekabet Gücü Kaynaği Olarak Entellektüel Sermaye Ve Organizasyonel Performansa Yansimalari. Journal of Aeronautics and Space Technologies, 1(3), 77-85.

Karacaer, S., \& Aygün, M. (2009). Entellektüel Sermayenin Firma Performansi Üzerindeki Etkisi. Hacettepe Üniversitesi İktisadi ve İdari Bilimler Fakültesi Dergisi, 27(2), 127-140. http://dergipark.org.tr/huniibf/issue/29259/313386

Karacan, S., (2004). Entelektüel Sermaye ve Yönetİm. ISSMMO Mal Çözüm Derg s, 69, 177-199.

Karacan, S., Ergin, E., (2011). Bankaların Entelektüel Sermayesi ile Finansal Performansı Arasındaki İlişki. Business and Economics Research Journal, Volume 2, Number 4, 73-88.

Kayali, C. A., Yereli, A. N., \& Şebnem, A. D. A. (2007). Entelektüel Katma Değer Katsayısı Yöntemi Kullanılarak Entelektüel Sermayenin Firma Değeri Üzerindeki Etkisinin Belirlenmesine Yönelik Bir Araştırma. Yönetim Ve Ekonomi: Celal Bayar Üniversitesi İktisadi Ve İdari Bilimler Fakültesi Dergisi, 14(1), 67-90. http://dergipark.org.tr/yonveek/issue/13686/165619

Kurgun, O., \& Akdağ, G. (2013). Entelektüel Sermaye Ve Örgüt Performansı Ilişkisi: Akdeniz Bölgesindeki Otel Işletmelerinde Bir Araştırma. Nevşehir Hacı Bektaş Veli Üniversitesi SBE Dergisi, 2(2), 155-176. http://dergipark.org.tr/nevsosbilen/issue/19735/211173

Marangoz, M., \& Biber, L. (2007). İşletmelerin pazar performansi ile insan kaynakları uygulamaları arasındaki ilişkinin araştırılmasına yönelik bir çalışma. Doğuş Üniversitesi Dergisi, 8 (2) 2007, 202-217

Mehmet, İ., (2005). Değişim Olgusu Ve Örgütlerde İnsan Kaynaklari Yönetiminin Değişsen Fonksiyonlari. Selçuk Üniversitesi Sosyal Bilimler Enstitüsü Dergisi, (14), 319-339.

Molodchik, M. A., Shakina, A. S., Bykova, A. A., (2012). Intellectual Capital Transformation Evaluating Model. Journal of Intellectual Capital, Vol. 13 Iss: 4, 444-461

Oğuztürk, B. S., \& Alparslan, A. M. (2011). E-Ticaret Stratejisinde Entelektüel Sermayenin Görünümü. Journal Of Suleyman Demirel University Institute Of Social Sciences, 13(1).

Ölçer, F., \& Şanal, M. (2007). İşletmelerde Entelektüel Sermaye Yönetimi. Çukurova Üniversitesi Sosyal Bilimler Enstitüsü Dergisi, 16(1), 479-500. http://dergipark.org.tr/cusosbil/issue/4376/59960 
Özdemir, L., \& Balkan, O. (2010). Entelektüel Sermaye Unsurlarinin İşletmelere Sağladiği Katkilar. Organizasyon Ve Yönetim Bilimleri Dergisi, 2(1), 115-121. http://dergipark.org.tr/oybd/issue/16335/171016

Özden, A., \& Çolak, H. , (2012). İnsan Kaynakları Yönetimi Uygulamalarıyla Örgütsel Performans Arasındaki Ilişki Üzerine Bir Araştırma. Çankırı Karatekin Üniversitesi Iibf Dergisi, 2(2), 85-114

Özer, P., Özmen, Ö. N., \& Saatçioğlu, Ö. Y. (2004). Bilgi Yönetiminin Etkililiğinde Kilit Bir Faktör Olarak Bilgi Işçileri Ve Insan Kaynakları Yönetiminin Farklılaşan Özellikleri. Dokuz Eylül Üniversitesi Sosyal Bilimler Enstitüsü Dergisi Cilt 6, Sayfa:1

Özevren, M., \& Yıldız, S. (2010). Entelektüel Sermayenin Ölçüm Yöntemleri Ve Kriterlerinin Belirlenmesi Üzerine Bir Araştirma. Marmara Üniversitesi İktisadi Ve Ídari Bilimler Dergisi, 29(2), 275-289.

Öztürk, M. B., \& Demirgüneş, K. (2008). Kurumsal Yönetim Bakişaçisiyla Entellektüel Sermaye. Selçuk Üniversitesi Sosyal Bilimler Enstitüsü Dergisi, (19), 395411.

Şerbetçi, D., (2003). 21. Yy Işletmelerinin Gerçek Zenginlik Kaynaği: Insan Sermayesi. Dumlupınar Üniversitesi Sosyal Bilimler Dergisi, (8). http://dergipark.org.tr/dpusbe/issue/4750/65250

Şimşek,Ş, Çelik, A, Akatay, A., (2016) -Insan Kaynakları Yönetimi ve Kariyer uygulamaları 3. Bask1 2016

Toraman, C., Abdioğlu, H., \& İşgüden, B. (2009). İşletmelerde İnovasyon Sürecinde Entelektüel Sermaye Ve Yönetim Muhasebesi Kapsaminda Değerlendirilmesi. Afyon Kocatepe Üniversitesi İktisadi Ve İdari Bilimler Fakültesi Dergisi, 11(1), 91-120. http://dergipark.org.tr/akuiibfd/issue/1627/20384

Yereli, A. N., \& Gerşil, G. (2005). Entellektüel Sermayeyi Ölçme Ve Raporlama Yöntemleri. Yönetim ve Ekonomi: Celal Bayar Üniversitesi İktisadi ve İdari Bilimler Fakültesi Dergisi, 12(2), 17-29.

Yıldız, S., (2011). Entelektüel sermayenin işletme performansına etkisi: bankacılık sektöründe bir araştırma. Anadolu Üniversitesi Sosyal Bilimler Dergisi Cilt 11. Sayı 3.

Yörük, N., \& Erdem, N. S. (2008). Entelektüel Sermaye Ve Unsurlarinin, İmkb’de İşlem Gören Otomotiv Sektörü Firmalarinin Finansal Performansi Üzerine Etkisi. Atatürk Üniversitesi İktisadi ve İdari Bilimler Dergisi, 22(2), 397-413. http://dergipark.org.tr/atauniiibd/issue/2694/35479 